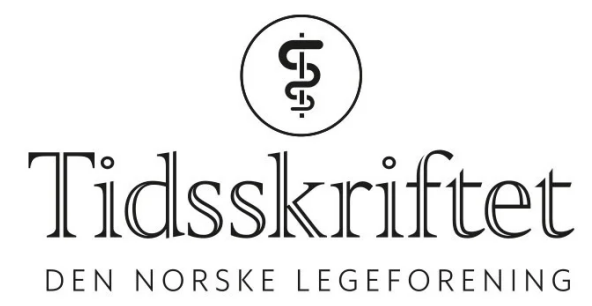

\title{
Studentprotest på vers
}

TIDLIGERE I TIDSSKRIFTET

ANNE KVEIM LIE

Email:a.h.k.lie@medisin.uio.no

Tidsskriftet

Studietiden kan bringe mange problemer, noen litt mer trengende enn andre. I slutten av 1920-årene hadde medisinstudentene på Rikshospitalet fått en stor ny garderobe med et dobbelt toalett tildelt hhv. kvinnelige og mannlige studenter. Men fordi guttene var så i overtall, okkuperte de også den doen som var avsatt til damene. Det medførte nedenstående kreative henvendelse fra jentene til ledelsen (Tidsskr Nor Lægeforen 1928; 48: 86-7). De fikk prompte svar fra selveste direktøren - også på vers. Selv om man neppe kan vente seg svar med samme mynt fra dagens direktører kan kanskje kommende protestanter la seg inspirere?

\section{O tempora, o mores!}

«Sturm und Drang»-poesi omkring R.H.s studentklosetter

Vi vil os beklage for vor direktør

og haaber De er vor ven som før.

Man tænker nok paa maskuline studenter;

men glemmer saa titt de studerende jenter.

Toilet har vi bare paa Gummisalen,

og, la os nu si det med likefrem talen,

at gaa paa dette er noksaa generlig,

og stigningen op er meget besværlig. 
Det er ikke godt naar tiden er knap

at løpe op fem etagers trap.

Vi ønsker at veien var mindre lang

og vandringen ikke en spissrotsgang.

Vi tør ikke gaa paa kirurgen B,

For «Over-Hanna» vil os ei se!

Da «Medicinen» nu færdig laa,

vi søkte et sted hvor vi kunde gaa,

og det vi fandt i den nye kjelder,

men tænk, det er ikke vort det heller!

Forleden dag da vi kom dit hen,

det stod paa døren «W.C. for menn»,

og vet De kjære hr. direktør

i gangen er der et slikt fra før!

Vil De nu være vor gode ven

saa la os faa vort «W.C.» igjen.

«Studiosi medicinae femininae».

Publisert: 27. august 2009. Tidsskr Nor Legeforen. DOI: 10.4045/tidsskr.09.0739

(C) Tidsskrift for Den norske legeforening 2023. Lastet ned fra tidsskriftet.no 26. april 2023. 